\title{
TECHNOLOGY ADOPTION AND TECHNICAL EFFICIENCY OF OIL PALM SMALLHOLDER PLANTATION IN RIAU AND WEST KALIMANTAN
}

\author{
Anto Ariyanto $^{* 11}$, Yusman Syaukat ${ }^{* *}$, Sri Hartoyo ${ }^{* * *}$, and Bonar M. Sinaga ${ }^{* *}$ \\ *) Agribusiness Study Program, Faculty of Agriculture, Lancang Kuning University \\ Jl. Yos Sudarso Km 8, Umban Sari, Rumbai, 28266 Pekanbaru, Indonesia \\ ${ }^{* *}$ Department of Resource and Environmental Economics, Faculty of Economics and Management, IPB University \\ Jl. Kamper Wing 4 Level 5 Kampus IPB, Dramaga16680 Bogor, Indonesia \\ ${ }^{* * *}$ Department of Economics, Faculty of Economics and Management, IPB University \\ Jl. Kamper Wing 4 Level 5 Kampus IPB, Dramaga16680 Bogor, Indonesia
}

\begin{abstract}
This study was conducted to assess the role of adoption of oil palm cultivation technology that has been recommended by the government (RI Regulation of the Minister of Agriculture No 131 / Permentan / OT.140 / 12/2013 concerning Guidelines for Good Oil Palm Cultivation) on production efficiency from smallholder plantations on the dependent smallholder and independent smallholder in Riau and West Kalimantan. Specifically, this study is: (1) to analyze the factors that influence the level of production and analyze the technical efficiency of smallholder oil palm in Riau and West Kalimantan, (2) to analyze the effect of intensity of technology adoption on productivity and efficiency of smallholder oil palm production in Riau and West Kalimantan, (3) To identify the factors affecting technical inefficiency in smallholder plantations in Riau and West Kalimantan. The research objectives were analyzed by using a stochastic frontier model to estimate productivity, the level of technical efficiency, and producer inefficiency simultaneously with allocative efficiency and economic efficiency. The results showed that smallholder oil palm farmers who adopt all recommended technologies compared to farmers who adopt not all recommended technologies had higher production efficiency. Analysis of technical efficiency showed that farmers in the dependent smallholder were more technically efficient than independent smallholders. Farmers who adopt more technology and had more experience, had higher efficiency than others. Farmers who were often associated with extension workers and more experience had higher efficiency than others.
\end{abstract}

Keywords: oil palm smallholder, technology adoption, technical efficiency, Riau, West Kalimantan

\begin{abstract}
Abstrak: Studi ini dilakukan untuk mengkaji peran adopsi teknologi budidaya kelapa sawit yang telah direkomendasikan oleh pemerintah (Peraturan Menteri Pertanian RI No 131/Permentan/ OT.140/12/2013 tentang Pedoman Budidaya Kelapa Sawit yang Baik) pada efisiensi produksi dari perkebunan rakyat pada pekebun rakyat dan pekebun mandiri di Riau dan Kalimantan Barat. Secara spesifik penelitian ini adalah (1) menganalisis faktor-faktor yang mempengaruhi tingkat produksi dan menganalisis efisiensi teknis petani sawit di Riau dan Kalimantan Barat, (2) menganalisis pengaruh intensitas adopsi teknologi terhadap produktivitas dan efisiensi. produksi kelapa sawit rakyat di Riau dan Kalimantan Barat, (3) Mengidentifikasi faktor-faktor yang mempengaruhi inefisiensi teknis di perkebunan rakyat di Riau dan Kalimantan Barat. Tujuan penelitian dianalisis dengan menggunakan model stochastic frontier untuk mengestimasi produktivitas, tingkat efisiensi teknis, dan inefisiensi produsen secara simultan dengan efisiensi alokatifdan efisiensi ekonomis. Hasil penelitian menunjukkan bahwa petani kecilyang mengadopsi semua teknologi yang direkomendasikan dibandingkan dengan petani yang mengadopsi tidak semua teknologi yang direkomendasikan memiliki efisiensi produksi yang lebih tinggi. Analisis efisiensi teknis menunjukkan bahwa petani pada pekebun swadaya lebih efisien secara teknis dibandingkan pekebun swadaya. Petani yang mengadopsi lebih banyak teknologi dan memiliki lebih banyak pengalaman, memiliki efisiensi yang lebih tinggi daripada yang lain. Petani yang sering dikaitkan dengan penyuluh dan lebih berpengalaman memiliki efisiensi yang lebih tinggi daripada yang lain.
\end{abstract}

Kata kunci: kelapa sawit rakyat, adopsi teknologi, efisiensi teknis, Riau, Kalimantan Barat

\footnotetext{
${ }^{1}$ Corresponding author:

Email: antoariyanto@unilak.ac.id
} 


\section{INTRODUCTION}

As the world's largest palm oil producer, Indonesia has a relatively lower productivity level compared to other major palm oil- producing countries (Zen Z et al. 2006; Woittiez LS et al. 2016; Ernah et al. 2016). This fact is indicated by Indonesia's average productivity level of only 16.87 tons per hectare per year in the form of fresh fruit bunches (FFB), which only ranks eighth in the world. It is Ffar behind compared to Guatemala, which was ranked first with a productivity level of 26.23 tons per hectare per year. Indonesia's competitors, namely Malaysia, ranked third with a productivity level of 21.77 tons per hectare per year (Ditjenbun, 2014). The low average level of Indonesian productivity is thought to be due to the relatively low contribution of productivity from smallholder farmers' plantation because oil palm is not only planted on large-scale plantations, but also with the local smallholders' involvement of local smallholders. The production of smallholder oil palm plantations is estimated to be only $50 \%$ lower than the potential results that can be achieved, while those of government Government and private plantations are estimated to have reached $85 \%-90 \%$ of the potential achieved (Lifianthi, 2012; Siswati L et al. 2012).

In smallholder oil palm cultivation in Indonesia, there are two types of farmers:, namely farmers with dependent smallholder and independent smallholders. Farmers in the dependent smallholder pattern are farmers who start oil palm cultivation with a management scheme under the guidance of the government or the private sector and the second, those who decide to adopt oil palm management independently (Baswir et al. 2010; Euler et al. 2015 and 2016; Vermeulen et al. 2006). In the partnership farmers, they supply their products to plantation companies or oil palm mills. Their relationship is based on contracts, while plantation companies remain responsible for technical and marketing assistance. While independent smallholder farmers are not bound or bound by contracts for plantation companies or CPO factories. They are free to sell to any buyer (Lee JSH et al. 2014)

The his research basic principle of this research is to find out how farmers who adopt recommended technology in full and farmers who do not adopt or only adopt a portion of recommended technology to the level of productivity and efficiency. And then to understand the factors that influence it. Thus the objectives of this study were: (1) to analyze the factors that influence the level of production and analyze the technical efficiency of smallholder oil palm in Riau and West Kalimantan, (2) to analyze the effect of intensity of technology adoption on productivity and efficiency of smallholder oil palm production in Riau and West Kalimantan, (3) To identify the factors affecting technical inefficiency in smallholder plantations in Riau and West Kalimantan.

\section{METHODS}

This research was carried out using secondary data derived from the 2014 survey of plantation business households, which had been carried out by BPS (Central Bureau of Statistics). The data used in this study selected 2 two smallholders of oil palm center provinces, namely Riau and West Kalimantan with a total of 2461 plantation households, which consists of 1915 households from Riau and 546 households from West Kalimantan. When viewed based on management patternsThese provinces, which consists of dependent smallholder patterns as many as 603 households and independent smallholder patterns as many as 1858 households., the The majority of smallholder oil palm farmers in Riau (89.4\%) were independent smallholder farmers, and in West Kalimantan the majority (73.26\%) were independent smallholder farmers. The criteria data used for this study was oil palm in the condition of yielding plants.

The production function model of the stochastic frontier is used to determine the factors that influence the production of smallholder oil palm plantations. To find out the factors that influence the production of smallholder oil palm plantations, the production function model of the stochastic frontier is used. The translog model is assumed to be part of the production limit. This model is relatively flexible because it does not impose assumptions about the constant elasticity of production or the elasticity of substitution between inputs.

The stochastic frontier production model applied in this study is (Amos, 2007; Alwarritzi et al. 2015; Hasnah et al. 2004) :

$$
\begin{aligned}
\operatorname{LnQ}_{\mathrm{it}}= & \beta_{\mathrm{o}}+\sum \beta_{\mathrm{j}} \operatorname{LnX} \mathrm{Xi}_{\mathrm{ji}}+ \\
& \frac{1}{2} \sum_{\mathrm{j}} \sum_{\mathrm{k}} \beta_{\mathrm{jk}} \operatorname{LnX}_{\mathrm{ji}} \operatorname{LnX}_{\mathrm{ki}}+\varepsilon_{\mathrm{i}}
\end{aligned}
$$


Where, Xi representsed standardized and normalized input variables with each sample before transformed and showed the estimated technological parameters. The variables are as follows: $\mathrm{Q}$ (productivity measured in TBS (ton/ha)); Ln (area (ha)); Urea (urea fertilizer (kg/ ha)); SP36 (SP36 fertilizer (kg/ ha)); MOP (MOP fertilizer ( $\mathrm{kg} / \mathrm{ha})$ ); Dol (dolomit fertilizer ( $\mathrm{kg} / \mathrm{ha})$ ); Pest (pestiside (liter/ha)); Tk (the number of manpower (people/ha)); UTM (the planting age (year)).

Technical efficiency analysis can be measured using the following formula:

$$
\mathrm{TEi}=\mathrm{E}[\exp (\mathrm{Ui}) / \varepsilon \mathrm{i}], \mathrm{i}=1,2,3, \ldots, \mathrm{n}
$$

Where: TEi (the technical efficiency of smallholder palm oil-i); $\exp (-\mathrm{E}[\mathrm{Ui} \mid \varepsilon i])$ (the expected value (mean) of ui with the $\varepsilon i$ condition).

The inefficiency effect model used refers to the inefficiency model developed by Battese and Coelli (1988). The value of technical efficiency is between $0 \leq$ $\mathrm{TE} \leq 1$. The value of smallholder plantations' technical efficiency of smallholder plantations is categorized as efficient enough if it is $\geq 0.7$ and is categorized as inefficient if it is $<0.7$ (Coelli et al. 2005; Coelli et al. 1996; Susanti et al. 2017).

The ui variable used to measure the effect of technical inefficiency is assumed to be free and its distribution is truncated normally with $\mathrm{N}\left(\mathrm{u}_{\mathrm{it}}, \zeta 2\right)$. To determine the value of the distribution parameter (ui) the effect of technical inefficiency is stated as follows:

$$
\mathrm{U}_{\mathrm{i}}=\delta_{0}+\delta_{1} \mathrm{Z}_{1}+\delta_{2} \mathrm{Z}_{2}+\delta_{3} \mathrm{Z}_{3}+\delta_{4} \mathrm{Z}_{4}+\delta_{5} \mathrm{Z}_{5}+\delta_{6} \mathrm{Z}_{6}
$$

Where: Ui (the effect of technical inefficiency); $\delta 0$ (intercept); Z1 (management pattern type $(1=$ dependent smallholder, $0=$ independent smallholder)); Z2 (adoption (the number of adopted technology)); Z3 (age of farmer respondent (respondent (year)); Z4 (dummy of counseling $(1=$ exist, $0=$ not exist $)$ ); Z5 (dummy of villageof village unit cooperatives (cooperatives $(1=$ member, $0=$ non member $)$ ); Z6 (dummy of credit access $(1=$ access $0=$ no access); Z7 (farmer income (Rp/hectare)).

\section{RESULTS}

\section{Smallholder Oil Palm Production Function in Riau}

The estimation of the Frontier translog stochastic model for smallholder oil palm farmers in Riau is presented in Table 1. All input variables in the model of smallholder oil palm farmers meet the expected criteria. The contribution of urea fertilizer, SP36 fertilizer, and MOP fertilizer was positive and very significant. This finding implies that urea, SP36 and MOP fertilizers were important factors in smallholder oil palm production in the study area, so the percentage increase in the amount of fertilizer will result in an increase in the total output of $0.02 \%$ and $0.015 \%$ and $0.028 \%$, respectively. Likewise, the number of workers and plant age are important factors in oil palm production in Riau.

The interaction coefficient between area (ha) and MOP fertilizer had a negative and significant effect at the 10\% level. It indicatesIt indicates that if the area (ha) and MOP fertilizer used are higher than other variables, then the oil palm productivity of oil palm will decrease. It is because tThe increasing area (ha) (extensification) will reduce the efficiency of oil palm production. However, it differs from the interaction between area (ha) and dolomite. The interaction has a positive and significant effect at the $10 \%$ level. It is indicating that increased land use and a dolomite increase oil palm productivity in Riau.However, it differs from the interaction between area (ha) and dolomite, which has a positive and significant effect at the $10 \%$ level, indicating that increased land use and dolomite increase oil palm productivity in Riau. The interaction between area (ha) and total employment has a positive and significant effect at the $5 \%$ level, implying that increases in co-use of land and labor lead to increased oil palm productivity of oil palm. The interaction coefficient between SP36 and dolomite fertilizers was negative and significant at $10 \%$. It implies the increase in co-use between SP36 and dolomite fertilizers causes a decrease in oil palm productivity. Consequently, the use of SP36 and dolomite together will reduce productivity.The interaction coefficient between SP36 and dolomite fertilizers was negative and significant at $10 \%$ that implies the increase in co-use between SP36 and dolomite fertilizers causes a decrease in oil palm productivity, this implies that the use of SP36 and dolomite together will reduce productivity. Likewise, the interaction between SP36 fertilizer and the number of workers has a negative and significant effect at the $5 \%$ 
level, implying that an increase in the joint use of SP36 fertilizer and the number of workers causes a decrease in oil palm productivity in Riau. he interaction between dolomite and pesticides was positive and significant at the $5 \%$ level, which similar to dolomite and labor interactionThe interaction coefficient between dolomite and pesticides was positive and significant at the 5\% level, as is the interaction between dolomite and labor.
This finding suggests that the increased use of dolomite with pesticides and dolomite with the number of workers together led to increased oil palm productivity in Riau.This suggests that the increased use of dolomite and pesticides as well as dolomite and the number of workers together led to increased productivity of oil palm in Riau.

Table1. Results of estimating the production function of oil palm per hectare in Riau (MLE translog method), in 2014

\begin{tabular}{|c|c|c|c|c|c|}
\hline Variable & Parameter & Coefficient & & Std Error & t-ratio \\
\hline Constants & $\beta 0$ & 1.217548 & & 0.212101 & 5.740424 \\
\hline Ln(Lahan) & $\beta 1$ & 0.044794 & & 0.086026 & 0.520700 \\
\hline Ln(Urea) & $\beta 2$ & 0.021070 & $* * *$ & 0.008502 & 2.478186 \\
\hline $\operatorname{Ln}(\mathrm{SP} 36)$ & $\beta 3$ & 0.015791 & $* *$ & 0.008599 & 1.836265 \\
\hline $\operatorname{Ln}(\mathrm{MOP})$ & $\beta 4$ & 0.028795 & $* * *$ & 0.010234 & 2.813586 \\
\hline $\operatorname{Ln}(\mathrm{Dol})$ & $\beta 5$ & 0.009435 & & 0.018332 & 0.514669 \\
\hline $\operatorname{Ln}($ Pest $)$ & $\beta 6$ & 0.013178 & & 0.013160 & 1.001373 \\
\hline $\operatorname{Ln}(\mathrm{Tk})$ & $\beta 7$ & 0.162860 & $* *$ & 0.080468 & 2.023914 \\
\hline $\operatorname{Ln}(\mathrm{UTM})$ & $\beta 8$ & 0.943129 & $* * *$ & 0.132895 & 7.096772 \\
\hline $0.5([\operatorname{Ln}($ Llahan $)] 2)$ & $\beta 11$ & 0.107140 & $* *$ & 0.061125 & 1.752787 \\
\hline $0.5([\operatorname{Ln}($ Urea $)] 2)$ & $\beta 22$ & 0.004112 & $* * *$ & 0.001398 & 2.940536 \\
\hline $0.5([\operatorname{Ln}(\mathrm{SP} 36)] 2)$ & $\beta 33$ & 0.004424 & $* * *$ & 0.001466 & 3.018689 \\
\hline $0.5([\operatorname{Ln}(\mathrm{MOP})] 2)$ & $\beta 44$ & 0.004416 & $* * *$ & 0.001577 & 2.800555 \\
\hline $0.5([\operatorname{Ln}(\mathrm{Dol})] 2)$ & $\beta 55$ & 0.003916 & & 0.003673 & 1.066379 \\
\hline $0.5([\operatorname{Ln}($ Pest $)] 2)$ & $\beta 66$ & 0.002199 & & 0.002090 & 1.052075 \\
\hline $0.5([\operatorname{Ln}(\mathrm{Tk})] 2)$ & $\beta 77$ & 0.086144 & $*$ & 0.060556 & 1.422549 \\
\hline $0.5([\operatorname{Ln}(\mathrm{UTM})] 2)$ & $\beta 88$ & -0.353564 & $* * *$ & 0.054602 & -6.475245 \\
\hline [Ln(Llahan)] [Ln(Urea)] & $\beta 12$ & 0.002671 & & 0.002587 & 1.032532 \\
\hline$[\operatorname{Ln}($ Llahan $)][\operatorname{Ln}(\mathrm{SP} 36)]$ & $\beta 13$ & 0.000333 & & 0.002732 & 0.121820 \\
\hline [Ln(Llahan)] [Ln(MOP)] & $\beta 14$ & -0.003847 & $*$ & 0.002663 & -1.444947 \\
\hline$[\operatorname{Ln}($ Llahan $)][\operatorname{Ln}(\mathrm{Dol})]$ & $\beta 15$ & 0.006709 & * & 0.003510 & 1.911297 \\
\hline [Ln(Llahan)] [Ln(Pest)] & $\beta 16$ & 0.001516 & & 0.002273 & 0.666784 \\
\hline$[\operatorname{Ln}($ Llahan $)][\operatorname{Ln}(\mathrm{Tk})]$ & $\beta 17$ & 0.115653 & $* *$ & 0.057284 & 2.018918 \\
\hline$[\operatorname{Ln}($ Llahan $)][\operatorname{Ln}(\mathrm{UTM})]$ & $\beta 18$ & -0.010967 & & 0.032905 & -0.333287 \\
\hline$[\operatorname{Ln}($ Urea $)][\operatorname{Ln}(\mathrm{SP} 36)]$ & $\beta 23$ & 0.000037 & & 0.000166 & 0.223713 \\
\hline [Ln(Urea)] [Ln(MOP)] & $\beta 24$ & -0.000188 & & 0.000163 & -1.151167 \\
\hline [Ln(Urea)] [Ln(Dol)] & $\beta 25$ & 0.000123 & & 0.000262 & 0.470329 \\
\hline$[\operatorname{Ln}($ Urea $)][\operatorname{Ln}($ Pest $)]$ & $\beta 26$ & -0.000067 & & 0.000161 & -0.415542 \\
\hline [Ln(Urea)] [Ln(Tk)] & $\beta 27$ & 0.001945 & & 0.002648 & 0.734780 \\
\hline [Ln(Urea)] [Ln(UTM)] & $\beta 28$ & -0.002182 & & 0.002515 & -0.867570 \\
\hline [Ln(SP36)] [Ln(MOP)] & $\beta 34$ & -0.000133 & & 0.000138 & -0.966645 \\
\hline [Ln(SP36)] [Ln(Dol)] & $\beta 35$ & -0.000253 & * & 0.000179 & -1.408930 \\
\hline$[\operatorname{Ln}(\mathrm{SP} 36)][\operatorname{Ln}($ Pest $)]$ & $\beta 36$ & -0.000062 & & 0.000139 & -0.444482 \\
\hline$[\operatorname{Ln}(\mathrm{SP} 36)][\mathrm{Ln}(\mathrm{Tk})]$ & $\beta 37$ & -0.004904 & $* *$ & 0.002568 & -1.909791 \\
\hline$[\mathrm{Ln}(\mathrm{SP} 36)][\mathrm{Ln}(\mathrm{UTM})]$ & $\beta 38$ & 0.000678 & & 0.001889 & 0.359074 \\
\hline
\end{tabular}


Table1. Results of estimating the production function of oil palm per hectare in Riau (MLE translog method), in 2014

\begin{tabular}{|c|c|c|c|c|c|}
\hline Variable & Parameter & Coefficient & & Std Error & t-ratio \\
\hline$[\operatorname{Ln}(\mathrm{MOP})][\mathrm{Ln}(\mathrm{Dol})]$ & $\beta 45$ & 0.000094 & & 0.000196 & 0.480096 \\
\hline$[\operatorname{Ln}(\mathrm{MOP})][\operatorname{Ln}($ Pest $)]$ & $\beta 46$ & 0.000081 & & 0.000156 & 0.517695 \\
\hline$[\operatorname{Ln}(\mathrm{MOP})][\mathrm{Ln}(\mathrm{Tk})]$ & $\beta 47$ & -0.001856 & & 0.002611 & -0.710684 \\
\hline$[\mathrm{Ln}(\mathrm{MOP})][\mathrm{Ln}(\mathrm{UTM})]$ & $\beta 48$ & -0.000257 & & 0.002676 & -0.096183 \\
\hline$[\operatorname{Ln}($ Dol $)][\operatorname{Ln}($ Pest $)]$ & $\beta 56$ & 0.000402 & ** & 0.000204 & 1.974823 \\
\hline$[\operatorname{Ln}(\mathrm{Dol})][\mathrm{Ln}(\mathrm{Tk})]$ & $\beta 57$ & 0.005677 & $* *$ & 0.003241 & 1.751711 \\
\hline$[\mathrm{Ln}(\mathrm{Dol})][\mathrm{Ln}(\mathrm{UTM})]$ & $\beta 58$ & 0.000449 & & 0.002697 & 0.166485 \\
\hline$[\operatorname{Ln}($ Pest $)][\operatorname{Ln}(\mathrm{Tk})]$ & $\beta 67$ & 0.005060 & ** & 0.002333 & 2.169119 \\
\hline$[\operatorname{Ln}($ Pest $)][\operatorname{Ln}(\mathrm{UTM})]$ & $\beta 68$ & 0.001712 & & 0.001727 & 0.991321 \\
\hline$[\operatorname{Ln}(\mathrm{Tk})][\mathrm{Ln}(\mathrm{UTM})]$ & $\beta 78$ & -0.024731 & & 0.029962 & -0.825416 \\
\hline Sigma-square $(\sigma 2)$ & & 0.650917 & & 0.066277 & 9.821203 \\
\hline Gamma $(\gamma)$ & & 0.997513 & $* * *$ & 0.001088 & 916.981160 \\
\hline log likelihood function & & & & & -870.161340 \\
\hline L-R test & & & & & 622.688050 \\
\hline
\end{tabular}

Description : ***,**, * : significant on the level of $\alpha=1 \%, 5 \%$, and $10 \%$

Source : Plantation household survey BPS, 2014 (processed)

This study shows that more attention must be paid to the use of fertilizers to increase their fertility rates, as a means of increasingto increase the productivity of the smallholder oil palm. ThusThus, a program to complement the existence of a subsidized fertilizer program will help increase output on smallholder oil palm plantations in Riau. In addition, oil palm requires a lot ofmuch fertilizer when it is young to help in shapinge the leaves and make larger fruit groups when oil palm produces fruit. It is shown that in the model, the age of the plant is positive and significant. With increasing age, the output increased by $0.94 \%$.

In addition, Table 1 shows that the gamma value $(\gamma)$ was 0.99 and had a significant influence on the level of 1 percent. This result means that technical efficiency differences caused $99 \%$ of the variation in smallholder oil palm farmers' results. In comparison, the remaining $1 \%$ percent was caused by stochastic effects outside the model, such as climate influences, natural disasters, pest and disease attacks. This means that $99 \%$ of the variation in results among smallholder oil palm farmers was caused by technical efficiency differences while the remaining $1 \%$ percent was caused by stochastic effects outside the model such as climate influences, natural disasters, pest and disease attacks. The gamma value $(\gamma)$ in this study was higher than the gamma value $(\gamma)$ in the study of Hasnah et al. (2004) on smallholder oil palm farmers in the dependent smallholder-trans scheme in West Sumatra of 0.94; Bonkole et al. (2018) in oil palm farmers in Edo state in Nigeria of 0.74. However, it is still lower than research by Alwarritzi et al. (2015) on oil palm farmers with a dependent smallholder-trans scheme in Pelalawan District of Riau with a value of more than 1. While in the research of Juyjaeng et al. (2019) on oil palm farmers members and non-members of the LAPS scheme in Prachuap Khiri Khan Province, Thailand with has the same value that was equal to 0.99 .

\section{Technical efficiency and inefficiency of Oil Palm Farmers in Riau}

Table 2 shows that smallholder oil palm farming in Riau was technically inefficient because the average value of technical efficiency was 0.60 with a value of technical efficiency ranging from 0.04 to 0.99 . According to Fadwiwati (2013); Situmorang (2013), Kumbakar and Lovell (2001), Bakhsh and Ahmad (2006), farming is efficient if it has an average value above 0.80 . Smallholder oil palm farming's technical efficiency in Riau in the dependent smallholder pattern was higher than that of smallholder oil palm farming in the independent smallholder pattern. This result is indicated by the average technical efficiency of oil palm farming in the dependent smallholder pattern of 0.78 with a range of 0.08 to 0.98 . The technical efficiency of smallholder oil palm farming in Riau in the dependent smallholder pattern was higher than that of smallholder oil palm farming in the independent smallholder pattern. 
This is indicated by the average technical efficiency of oil palm farming in the dependent smallholder pattern of 0.78 with a range of 0.08 to 0.98 . Whereas in the independent smallholder pattern of smallholder oil palm farming, the average value of technical efficiency was only 0.58 with a range of 0.04 to 0.99 . The average variation value of technical efficiency in the dependent smallholder pattern and the independent smallholder pattern looked very high because farmers have entered the old plant age.The variation average value of technical efficiency in the dependent smallholder pattern and the independent smallholder pattern looked very high because there are farmers that have entered old plant age. In addition, it is due to otherto other reasons, namely the various land areas.

These results indicate that in Riau as a whole, smallholder oil palm farmers can increase technical efficiency at the technology level and existing inputs by $40 \%$ (1-0.60/0.99) in Riau as a whole. On smallholder oil palm farming with dependent smallholder patterns, farmers can increase technical efficiency at the technology level and existing inputs by $22.22 \%$ (1-0.78/0.98), and on oil palm farming with independent smallholder' patterns can increase the technical efficiency of farming by $42.2 \%(1-0.58 / 0.99)$.

Differences in the level of technical efficiency achieved by farmers in the study locations indicate different levels of mastery and application of technology and farming management. The difference in the application of technology is in terms of the use of production inputs besides being caused by the level of mastery of technology, also due toand the ability of farmers to obtain production inputs related to farmer capital.

While in Table 3 shows that smallholder oil palm farming in Riau is technically based on the level of technology adoption. It can be seen that farmers who adopted the technology are getting better levels of technical efficiency and better production levels. Farmers who did not adopt technology had an average technical efficiency of 0.51 , with an average production of 10.4 tons/ha. It is lower than oil palm farmers in the partial adopter and full adopter categories, namely, each with a technical efficiency level of 0.60 average productions of 13.47 tons/ha and 0.66 with an average production of 15.53 tons/ha.Farmers who did not adopt technology only had an average technical efficiency of 0.51 with an average number of production of 10.4 tons/ha, which is lower compared to oil palm farmers in the partial adopter and full adopter categories, namely each with a technical efficiency level of 0.60 average production of 13.47 tons/ha and 0.66 with an average production of 15.53 tons/ha. This finding shows that the adoption of technology can improve the level of efficiency and production of FFB of smallholder oil palm farmers in Riau.

Table 2.The results of the technical efficiency of smallholder oil palm- based on management pattern

\begin{tabular}{|c|c|c|c|c|c|c|}
\hline \multirow{2}{*}{$\begin{array}{c}\text { Level of } \\
\text { Technical } \\
\text { Efficiency } \\
(\%)\end{array}$} & \multicolumn{2}{|c|}{ Dependent smallholder } & \multicolumn{2}{|c|}{ Independent smallholder } & \multicolumn{2}{|c|}{ Combination } \\
\hline & $\begin{array}{c}\text { Number of } \\
\text { Farmer }\end{array}$ & Percentage $(\%)$ & $\begin{array}{l}\text { Number of } \\
\text { Farmer }\end{array}$ & Percentage $(\%)$ & $\begin{array}{c}\text { Number of } \\
\text { Farmer }\end{array}$ & Percentage $(\%)$ \\
\hline $0-10$ & 1 & 0.49 & 30 & 1.75 & 31 & 1.62 \\
\hline $11-20$ & 0 & 0.00 & 60 & 3.50 & 60 & 3.13 \\
\hline $21-30$ & 5 & 2.46 & 116 & 6.78 & 121 & 6.32 \\
\hline $31-40$ & 3 & 1.48 & 199 & 11.62 & 202 & 10.55 \\
\hline $41-50$ & 10 & 4.93 & 267 & 15.60 & 277 & 14.46 \\
\hline $51-60$ & 19 & 9.36 & 274 & 16.00 & 293 & 15.30 \\
\hline $61-70$ & 24 & 11.82 & 226 & 13.20 & 250 & 13.05 \\
\hline $71-80$ & 26 & 12.81 & 214 & 12.50 & 240 & 12.53 \\
\hline $81-90$ & 37 & 18.23 & 166 & 9.70 & 203 & 10.60 \\
\hline $91-100$ & 78 & 38.42 & 160 & 9.35 & 238 & 12.43 \\
\hline Total & 203 & 100.00 & 1712 & 100.00 & 1915 & 100.00 \\
\hline Minimum & 8.50 & & 4.10 & & 4.10 & \\
\hline Maximum & 98.31 & & 98.63 & & 98.63 & \\
\hline Average & 78.31 & & 57.84 & & 60.01 & \\
\hline
\end{tabular}

Source : Plantation household survey BPS, 2014 (processed) 
Differences in the level of technical efficiency achieved by farmers in the study locations indicate different levels of mastery and application of technology and farming management. The difference in the application of technology is in terms of the use of production inputs besides being caused by the level of mastery of technology, also due to, and the ability of farmers to obtain production inputs related to farmers' capital.

In addition to analyzing technical efficiency, this study also analyzed the factors that influence smallholder oil palm farming's technical inefficiency in Riau. Six variables areIn addition to analyzing technical efficiency, this study also analyzed the factors that influence the technical inefficiency of smallholder oil palm farming in Riau. There were six variables that are suspected to be sources of technical inefficiencies in oil palm farming, namely management patterns (Z1), technology adoption (Z2), farmer's age (Z3), counseling (Z4), Village Unit Cooperative membership (Z5) and credit access (Z6).

Table 4 shows that the management pattern variables, technology adoption, age of farmers, counseling, Village Unit Cooperative membership, and access to credit were negatively marked on smallholder oil palm farming's inefficiency. Of the six variables, only management pattern variables, technology adoption, membership in Village Unit Cooperative, and access to credit had a significant influence on the level of $1 \%$ on smallholder oil palm farming's inefficiency in Riau Province. Table 4 shows that the management pattern variables, technology adoption, age of farmers, counseling, Village Unit Cooperative membership and access to credit were negatively marked on the inefficiency of smallholder oil palm farming. Of the six variables only management pattern variables, technology adoption, membership in Village Unit Cooperative, and access to credit had a significant influence on the level of $1 \%$ on the inefficiency of smallholder oil palm farming in Riau Province.

The dependent smallholder and independent smallholder's management pattern had a significant influence at the level of $1 \%$. This influence means that independent smallholder patterns can reduce smallholder oil palm farming's technical inefficiency in Riau. Simultaneously, the dependent smallholder pattern will be easier to accept or adopt technological changes so that it affects the management of farming and will reduce inefficiency in farming. The management pattern of the dependent smallholder and independent smallholder had a significant influence at the level of $1 \%$. This means that the form of independent smallholder patterns can reduce the technical inefficiency of smallholder oil palm farming in Riau. While the dependent smallholder pattern will be easier to accept or adopt technological changes so that it affects the management of farming and this will reduce inefficiency in farming.

Table 3. Results of technical efficiency of smallholder oil palm farmers based on technology adoption in Riau

\begin{tabular}{|c|c|c|c|c|c|c|}
\hline \multirow{2}{*}{$\begin{array}{l}\text { Level of Technical } \\
\text { Efficiency }(\%)\end{array}$} & \multicolumn{2}{|c|}{ Non Adopter } & \multicolumn{2}{|c|}{ Partial Adopter } & \multicolumn{2}{|c|}{ Full Adopter } \\
\hline & $\begin{array}{c}\text { Number of } \\
\text { Farmer }\end{array}$ & $\begin{array}{c}\text { Percentage } \\
(\%)\end{array}$ & $\begin{array}{l}\text { Number of } \\
\text { Farmer }\end{array}$ & $\begin{array}{c}\text { Percentage } \\
(\%)\end{array}$ & $\begin{array}{c}\text { Number of } \\
\text { Farmer }\end{array}$ & $\begin{array}{c}\text { Percentage } \\
(\%)\end{array}$ \\
\hline $0-10$ & 1 & 0.49 & 30 & 1.75 & 31 & 1.62 \\
\hline $11-20$ & 0 & 0.00 & 60 & 3.50 & 60 & 3.13 \\
\hline $21-30$ & 5 & 2.46 & 116 & 6.78 & 121 & 6.32 \\
\hline $31-40$ & 3 & 1.48 & 199 & 11.62 & 202 & 10.55 \\
\hline $41-50$ & 10 & 4.93 & 267 & 15.60 & 277 & 14.46 \\
\hline $51-60$ & 19 & 9.36 & 274 & 16.00 & 293 & 15.30 \\
\hline $61-70$ & 24 & 11.82 & 226 & 13.20 & 250 & 13.05 \\
\hline $71-80$ & 26 & 12.81 & 214 & 12.50 & 240 & 12.53 \\
\hline $81-90$ & 37 & 18.23 & 166 & 9.70 & 203 & 10.60 \\
\hline $91-100$ & 78 & 38.42 & 160 & 9.35 & 238 & 12.43 \\
\hline Total & 203 & 100.00 & 1712 & 100.00 & 1915 & 100.00 \\
\hline Minimum & 4.10 & & 5.47 & & 8.83 & \\
\hline Maximum & 98.63 & & 98.39 & & 98.36 & \\
\hline Average of Technical Efficiency (\%) & 50.83 & & 60.31 & & 66.52 & \\
\hline Average of FFB production (ton/ha) & 10.40 & & 13.47 & & 15.53 & \\
\hline
\end{tabular}

Source : Plantation household survey BPS, 2014 (processed) 
Table 4. The results of estimating parameters model on the influence of technical inefficiencies in the production function of the stochastic frontier of smallholder oil palm farmer in Riau, 2014

\begin{tabular}{lcccc}
\hline \multicolumn{1}{c}{ Variable } & Coefficient & & Standard-error & t-ratio \\
\hline Constant & 1.024786 & & 0.147153 & 6.964075 \\
Dummy of Management Pattern (z1) & -0.644000 & $* * *$ & 0.207610 & -3.101967 \\
Technology Adoption(z2) & -0.015840 & $* * *$ & 0.001894 & -8.363994 \\
Age of Farmer (z3) & -0.002898 & & 0.002587 & -1.120225 \\
Dummy of Counseling (z4) & -0.038179 & & 0.139568 & -0.273553 \\
Dummy of Village Unit Cooperative & -0.867982 & $* * *$ & 0.191778 & -4.525970 \\
membership (z5) & & & & \\
Dummy of Credit Access (z6) & -0.250649 & $* * *$ & 0.088938 & -2.818251 \\
\hline
\end{tabular}

Description : ***,**, $*$ : significant on the level of $\alpha=1 \%, 5 \%$, and $10 \%$

Source : Plantation household survey BPS, 2014 (processed)

The credit access dummy variable had a coefficient of -0.25 and has a significant influence at the level of $1 \%$. Farmers who access credit can reduce the level of technical inefficiency in oil palm farming in Riau. his efficiency is because, with access to credit, farmers can get capital to buy farming inputs and do farming so that they can get maximum production results. This is because with the access to credit farmers can get capital to buy farming inputs and do farming so that they can get maximum production results.

\section{Smallholder Oil Palm Production Function in West Kalimantan}

The results of estimating the translog production function using the MLE method on smallholder oil palm farming in West Kalimantan can be seen in Table 5. It shows that the gamma value $(\gamma)$ was 0.92 and had a significant effect on 1 percent. This effect means that technical efficiency differences caused $92 \%$ of the variation in smallholder oil palm farmers in West Kalimantan. In comparison, the remaining $1 \%$ was caused by stochastic effects outside the model, such as climate influences, natural disasters, pests, and disease attacksIt shows that the gamma value $(\gamma)$ was 0.92 and had a significant effect on the level of $1 \%$. This means that $92 \%$ of the variation in results among smallholder oil palm farmers in West Kalimantan was caused by differences in technical efficiency while the remaining $1 \%$ percent was caused by stochastic effects outside the model such as climate influences, natural disasters, pest and disease attacks. The value of the generalizedlikelihood (LR) ratio in this study was 772.99, which was still greater than the real Kodde and Palm table values at $\alpha=5 \%$. This value means that there were influences on the efficiency and technical inefficiencies of farmers. The parameter estimation value (estimate parameter) in the stochastic frontier production function can show the elasticity value of the inputs used. Input variables that significantly influenced had a significant influence on smallholder oil palm production in West Kalimantan were land area and SP36 fertilizer.

The interaction coefficient between area (ha) and SP36 fertilizer had a positive and significant effect at the $10 \%$ level, that indicatesing that if the area (ha) and SP36 fertilizer used are higher, oil palm productivity in West Kalimantan will decrease. he difference with the interaction coefficient between SP36 and MOP fertilizers was negative and significant at $1 \%$. The difference implies that the increase in the joint use of SP36 and MOP fertilizers causes a decrease in oil palm productivity. This decrease implies that the use of SP36 and MOP together will reduce coconut productivity oil palm in West Kalimantan.The difference with the interaction coefficient between SP36 and MOP fertilizers was negative and significant at $1 \%$ that implies that the increase in joint use of SP36 and MOP fertilizers causes a decrease in oil palm productivity, this implies that the use of SP36 and MOP together will reduce coconut productivity oil palm in West Kalimantan. Likewise, the interaction between SP36 fertilizers and pesticides and SP36 fertilizers and the number of workers had a negative and significant impact at the $10 \%$ level, implying that the increased joint use of SP36 fertilizers and pesticides and the number of workers led to a decrease in oil palm productivity in West Kalimantan. The interaction coefficient between pesticides and oil palm plant age was positive and significant at $1 \%$. That implies that the increase in pesticides based on plant age leads to increased oil palm productivity in West KalimantanThe interaction coefficient between pesticides and dolomite oil palm plant age was positive and significant at $1 \%$ that implies the increase of the use of pesticides and 
plant age leads to increased productivity of oil palm in West Kalimantan.

The land area variable had a significant influence on the level of $5 \%$ and had a coefficient of -0.11 . Thus, if the input land area is raised by $1 \%$, it will reduce oil palm production by $0.11 \%$. The SP36 fertilizer variable had a significant influence on the level of 5\% and had a coefficient of 0.018 . This finding means that every addition of $1 \%$ SP36 fertilizer input will increase production by $0.018 \%$. The use of SP36 fertilizer can increase soil fertility so that it can increase the growth of oil palm plants. Land area variable had a significant influence on the level of 5\% and had a coefficient of -0.11 . This means that if the use of input land area is raised by $1 \%$, it will reduce oil palm production by $0.11 \%$. The SP36 fertilizer variable had a significant influence on the level of $5 \%$ and had a coefficient of 0.018 . this means that every addition of $1 \%$ SP36 fertilizer input will increase production by $0.018 \%$. The use of SP36 fertilizer can function to increase soil fertility so that it can increase the growth of oil palm plants.

Table 5. Results of estimating the production function of oil palm per tree in West Kalimantan (MLE translog method), in 2014

\begin{tabular}{|c|c|c|c|c|c|}
\hline Variable & Parameter & Coefficient & & Std Error & t-ratio \\
\hline Constant & $\beta 0$ & 3.061627 & & 0.099511 & 30.766689 \\
\hline Ln(Llahan) & $\beta 1$ & -0.112827 & $* *$ & 0.064635 & -1.745607 \\
\hline Ln(Urea) & $\beta 2$ & 0.004861 & & 0.007951 & 0.611375 \\
\hline Ln(SP36) & $\beta 3$ & 0.018110 & $* *$ & 0.009253 & 1.957315 \\
\hline $\operatorname{Ln}(\mathrm{MOP})$ & $\beta 4$ & 0.005691 & & 0.009854 & 0.577463 \\
\hline $\operatorname{Ln}($ Pest $)$ & $\beta 6$ & 0.016129 & & 0.014474 & 1.114286 \\
\hline Ln(UTM) & $\beta 8$ & -0.175723 & & 0.839400 & -0.209344 \\
\hline $0.5([\operatorname{Ln}($ Llahan $)] 2)$ & $\beta 11$ & 0.001551 & & 0.050384 & 0.030779 \\
\hline $0.5([\operatorname{Ln}($ Urea $)] 2)$ & $\beta 22$ & 0.001464 & & 0.001610 & 0.909385 \\
\hline $0.5([\operatorname{Ln}(\mathrm{SP} 36)] 2)$ & $\beta 33$ & 0.005834 & $* * *$ & 0.001882 & 3.099282 \\
\hline $0.5([\operatorname{Ln}(\mathrm{MOP})] 2)$ & $\beta 44$ & 0.000207 & & 0.001869 & 0.110990 \\
\hline $0.5([\operatorname{Ln}($ Pest $)] 2)$ & $\beta 66$ & 0.001732 & & 0.002256 & 0.767695 \\
\hline $0.5([\operatorname{Ln}(\mathrm{UTM})] 2)$ & $\beta 88$ & -4.675493 & & 7.892571 & -0.592392 \\
\hline [Ln(Llahan)] [Ln(Urea)] & $\beta 12$ & 0.002467 & & 0.004734 & 0.521032 \\
\hline$[\operatorname{Ln}($ Llahan $)][\operatorname{Ln}(\mathrm{SP} 36)]$ & $\beta 13$ & 0.005737 & $*$ & 0.004226 & 1.357347 \\
\hline$[\operatorname{Ln}($ Llahan $)][\operatorname{Ln}(\mathrm{MOP})]$ & $\beta 14$ & -0.002874 & & 0.004543 & -0.632523 \\
\hline [Ln(Llahan)] [Ln(Pest)] & $\beta 16$ & -0.004615 & & 0.003703 & -1.246144 \\
\hline$[\operatorname{Ln}($ Llahan $)][\operatorname{Ln}(\mathrm{UTM})]$ & $\beta 18$ & 0.087992 & & 0.355259 & 0.247685 \\
\hline [Ln(Urea)] [Ln(SP36)] & $\beta 23$ & -0.000208 & & 0.000469 & -0.443294 \\
\hline [Ln(Urea)] [Ln(MOP)] & $\beta 24$ & -0.000146 & & 0.000333 & -0.439967 \\
\hline [Ln(Urea)] [Ln(Pest)] & $\beta 26$ & 0.000152 & & 0.000396 & 0.385007 \\
\hline [Ln(Urea)] [Ln(UTM)] & $\beta 28$ & -0.007997 & & 0.031615 & -0.252959 \\
\hline$[\mathrm{Ln}(\mathrm{SP} 36)][\mathrm{Ln}(\mathrm{MOP})]$ & $\beta 34$ & -0.000466 & $* * *$ & 0.000182 & -2.559176 \\
\hline [Ln(SP36)] [Ln(Pest)] & $\beta 36$ & -0.000312 & $*$ & 0.000217 & -1.439724 \\
\hline [Ln(SP36)] [Ln(UTM)] & $\beta 38$ & -0.032195 & $*$ & 0.023914 & -1.346258 \\
\hline [Ln(MOP)] [Ln(Pest)] & $\beta 46$ & -0.000037 & & 0.000258 & -0.143346 \\
\hline [Ln(MOP)] [Ln(UTM)] & $\beta 48$ & -0.030093 & & 0.026617 & -1.130591 \\
\hline$[\operatorname{Ln}($ Pest $)][\operatorname{Ln}(\mathrm{UTM})]$ & $\beta 68$ & 0.056588 & $* * *$ & 0.021107 & 2.680970 \\
\hline Sigma-square $(\sigma 2)$ & & 0.054152 & $* * *$ & 0.004343 & 12.469904 \\
\hline $\operatorname{Gamma}(\gamma)$ & & 0.929999 & $* * *$ & 0.028658 & 32.452152 \\
\hline log likelihood function & & 148.655220 & & & \\
\hline L-R test & & 772.990890 & & & \\
\hline
\end{tabular}

Description : ***,**, * : significant on the level of $\alpha=1 \%, 5 \%$, and $10 \%$

Source : Plantation household survey BPS, 2014 (processed) 
Technical efficiency and inefficiency of Oil Palm Farmers in West Kalimantan

Table 6 shows that oil palm farming in the dependent smallholder in West Kalimantan was technically inefficient. The average value of technical efficiency was 0.74 , with a value of the technical efficiency range of 0.21 to 0.94 . While oil palm farming's technical efficiency in independent smallholder pattern was slightly lower than that of smallholder oil palm farming, the partnership pattern is indicated by the average technical efficiency of oil palm farming in self-help patterns of 0.70 with a range of 0.11 to 0.95 . While in combination with the smallholder oil palm farming in West Kalimantan, the average value of technical efficiency was 0.73 , with a range of 0.11 to 0.95. These results indicate that in West Kalimantan as a whole, farmers can improve technical efficiency at the technology level, and the input was $27.5 \%$ (1-0.73/0.98).Table 6 shows that oil palm farming in dependent smallholder in West Kalimantan was technically inefficient because the average value of technical efficiency was 0.74 with a value of the range of technical efficiency of 0.21 to 0.94 . While the technical efficiency of oil palm farming in independent smallholder pattern was slightly lower than that of smallholder oil palm farming, the partnership pattern is indicated by the average technical efficiency of oil palm farming in self-help patterns of 0.70 with a range of 0.11 to 0.95 . While in combination on the smallholder oil palm farming in West Kalimantan the average value of technical efficiency was 0.73 with a range of 0.11 to 0.95 . These results indicate that in West Kalimantan as a whole, farmers can improve technical efficiency at the technology level and the input was $27.5 \%$ (1-0.73/0.98).

While in Table 7 shows that smallholder oil palm farming in West Kalimantan is technically based on the level of technology adoption. It can be seen that farmers who adopt technology were getting better levels of technical efficiency and better production levels. Non-adopter smallholder oil palm farmers only had an average technical efficiency of 0.46 with an average production of 9.72 tons/ha, lower than oil palm farmers in the partial adopter and full adopter categories, each with a technical efficiency level of 0.58 with an average production of 13.6 tons/ha and 0.64 with an average production of 15.40 tons/ha. This result shows that the adoption of technology can improve the level of efficiency and production of FFB of smallholder oil palm farmers in West Kalimantan.

Table 6. Results of technical efficiency of smallholder oil palm farmers in West Kalimantan

\begin{tabular}{|c|c|c|c|c|c|c|}
\hline \multirow{2}{*}{$\begin{array}{l}\text { Level of Technical } \\
\text { Efficiency }(\%)\end{array}$} & \multicolumn{2}{|c|}{ Dependent smallholder } & \multicolumn{2}{|c|}{ Independent smallholder } & \multicolumn{2}{|c|}{ Combination } \\
\hline & $\begin{array}{c}\text { Number of } \\
\text { Farmer }\end{array}$ & $\begin{array}{c}\text { Percentage } \\
(\%)\end{array}$ & $\begin{array}{l}\text { Number of } \\
\text { Farmer }\end{array}$ & $\begin{array}{c}\text { Percentage } \\
(\%)\end{array}$ & $\begin{array}{l}\text { Number of } \\
\text { Farmer }\end{array}$ & $\begin{array}{c}\text { Percentage } \\
(\%)\end{array}$ \\
\hline $0-10$ & 0 & 0.00 & 0 & 0.00 & 0 & 0.00 \\
\hline $11-20$ & 0 & 0.00 & 2 & 1.37 & 2 & 0.37 \\
\hline $21-30$ & 9 & 2.25 & 3 & 2.05 & 12 & 2.20 \\
\hline $31-40$ & 16 & 4.00 & 11 & 7.53 & 27 & 4.95 \\
\hline $41-50$ & 12 & 3.00 & 12 & 8.22 & 24 & 4.40 \\
\hline $51-60$ & 30 & 7.50 & 20 & 13.70 & 50 & 9.16 \\
\hline $61-70$ & 51 & 12.75 & 8 & 5.48 & 59 & 10.81 \\
\hline $71-80$ & 88 & 22.00 & 26 & 17.81 & 114 & 20.88 \\
\hline $81-90$ & 160 & 40.00 & 51 & 34.93 & 211 & 38.64 \\
\hline $91-100$ & 34 & 8.50 & 13 & 8.90 & 47 & 8.61 \\
\hline Total & 400 & 100.00 & 146 & 100.00 & 546 & 100.00 \\
\hline Maximum & 93.96 & & 94.72 & & 94.72 & \\
\hline Minimum & 20.94 & & 11.10 & & 11.10 & \\
\hline Average & 74.63 & & 70.30 & & 73.47 & \\
\hline
\end{tabular}

Source : Plantation household survey BPS, 2014 (processed) 
An addition to analyzing technical efficiency, some factors influence smallholder oil palm farming's technical inefficiency in West Kalimantan. Five variables are suspected to be sources of technical inefficiencies in oil palm farming, namely farmer's age (Z1), Education (Z2), oil palm cultivation experience (Z3), number of family members (Z4), and a dummy of access to credit (Z5).In addition to analyzing technical efficiency, there were factors that influence the technical inefficiency of smallholder oil palm farming in West Kalimantan. There were five variables that are suspected to be sources of technical inefficiencies in oil palm farming, namely farmer's age (Z1), Education (Z2), oil palm cultivation experience (Z3), Number of family members (Z4), and dummy of access to credit (Z5).
Table 8 shows that management pattern technology adoption, farmer's age, counseling, Village Unit Cooperative membership, access to credit, and income were negatively marked by smallholder oil palm farming's inefficiency in West Kalimantan. From the seven variables, management pattern, technology adoption, Village Unit Cooperative membership, credit access, and farmer's income significantly influenced oil palm farming's inefficiency in West Kalimantan.Table 8 shows that management pattern technology adoption, farmer's age, counseling, Village Unit Cooperative membership, access to credit and income were negatively marked by the inefficiency of smallholder oil palm farming in West Kalimantan. From the seven variables, management pattern, technology adoption, Village Unit Cooperative membership, credit access, and farmer's income significantly influenced the inefficiency of oil palm farming in West Kalimantan.

Table 7. Results of technical efficiency of smallholder oil palm farmers based on technology adoption in West Kalimantan

\begin{tabular}{|c|c|c|c|c|c|c|}
\hline \multirow{2}{*}{$\begin{array}{l}\text { Level of Technical } \\
\text { Efficiency (\%) }\end{array}$} & \multicolumn{2}{|c|}{ Non Adopter } & \multicolumn{2}{|c|}{ Partial Adopter } & \multicolumn{2}{|c|}{ Full Adopter } \\
\hline & $\begin{array}{c}\text { Number of } \\
\text { Farmer }\end{array}$ & $\begin{array}{c}\text { Percentage } \\
(\%)\end{array}$ & $\begin{array}{c}\text { Number of } \\
\text { Farmer }\end{array}$ & $\begin{array}{c}\text { Percentage } \\
(\%)\end{array}$ & $\begin{array}{l}\text { Number of } \\
\text { Farmer }\end{array}$ & $\begin{array}{c}\text { Percentage } \\
(\%)\end{array}$ \\
\hline $0-10$ & 1 & 2.86 & 0 & 0.00 & 0 & 0.00 \\
\hline $11-20$ & 4 & 11.43 & 4 & 3.23 & 8 & 2.07 \\
\hline $21-30$ & 10 & 28.57 & 8 & 6.45 & 17 & 4.39 \\
\hline $31-40$ & 2 & 5.71 & 21 & 16.94 & 21 & 5.43 \\
\hline $41-50$ & 4 & 11.43 & 16 & 12.90 & 40 & 10.34 \\
\hline $51-60$ & 1 & 2.86 & 24 & 19.35 & 94 & 24.29 \\
\hline $61-70$ & 6 & 17.14 & 14 & 11.29 & 51 & 13.18 \\
\hline $71-80$ & 2 & 5.71 & 11 & 8.87 & 42 & 10.85 \\
\hline $81-90$ & 3 & 8.57 & 8 & 6.45 & 63 & 16.28 \\
\hline $91-100$ & 2 & 5.71 & 18 & 14.52 & 51 & 13.18 \\
\hline Total & 35 & 100.00 & 124 & 100.00 & 387 & 100.00 \\
\hline Minimum & 6.92 & & 15.81 & & 14.99 & \\
\hline Maximum & 96.22 & & 96.96 & & 98.41 & \\
\hline Average of ET (\%) & 46.30 & & 58.26 & & 64.94 & \\
\hline Average of FFB production (ton/ha) & 9.72 & & 13.60 & & 15.40 & \\
\hline
\end{tabular}

Source : Plantation household survey BPS, 2014 (processed) 
Table 8. The results of estimating parameters model on the influence of technical inefficiencies in the production function of the stochastic frontier of smallholder oil palm farmer in West Kalimantan, 2014

\begin{tabular}{lcccc}
\hline \multicolumn{1}{c}{ Variable } & Coefficient & & Standard-error & t-ratio \\
\hline Constant & 0.121153 & & 0.045595 & 2.657171 \\
Dummy of Management Pattern & -0.004860 & $* * *$ & 0.001064 & -4.569964 \\
Technology Adoption & -0.002278 & $* *$ & 0.001133 & -2.010504 \\
Farmer age & -0.003825 & & 0.004617 & -0.828631 \\
Dummy of Counseling & -0.006334 & & 0.034373 & -0.184266 \\
DummyVillage Unit Cooperative & -0.060689 & $* *$ & 0.033442 & -1.814785 \\
Dummy of Credit Access & -0.114128 & $* * *$ & 0.033018 & -3.456541 \\
Farmers' income & -0.000061 & $* * *$ & 0.000003 & -20.800458 \\
\hline
\end{tabular}

Description : $* * * * *, *$ : significant on the level of $\alpha=1 \%, 5 \%$, and $10 \%$

Source : Plantation household survey BPS, 2014 (processed)

\section{Managerial Implications}

When smallholder oil palm farmers increase the intensity of technology adoption and their productivity, they are self-help patterns by adopting all recommended palm oil technologies, will be more productive. When smallholder oil palm farmers increase the intensity of technology adoption, their productivity increases. Therefore, because smallholders, especially selfhelp patterns by adopting all recommended palm oil technologies, will be more productive. It is shown that farmers who adopt technology were higher in productivity than oil palm farmers who were not adopters or partial adopters of the recommended technologies.

The occurrence of inefficiencies was found among smallholder oil palm farmers. Hence, the number of technological improvements adopted was found to improve smallholder oil palm farmers' efficiency. Thus, smallholder's management pattern was proven to increase efficiency among dependent smallholder and independent smallholders. Moreover, counseling had also been proven to increase efficiency among smallholders. In other words, if farmers can gain access to better technology and extension services, it might help reduce inefficiencies in palm oil production.It is shown that farmers who adopt technology were higher in productivity compared to oil palm farmers who were not adopter or partial adopter of the recommended technologies.

The occurrence of inefficiencies was found among smallholder oil palm farmers. The number of technological improvements adopted was found to improve the efficiency of smallholder oil palm farmers. The management pattern of smallholder oil palm was proven to increase efficiency among farmers in dependent smallholder and independent smallholder. And counseling had also been proven to increase efficiency among smallholders. In other words, if farmers can gain access to better technology, and extension services, it might help reduce inefficiencies in palm oil production.

\section{CONCLUSIONS AND RECOMMENDATIONS}

\section{Conclusions}

Positive significant factors that intensity level of technology adoption in Riau are access to credit, members of farmer groups and assistance to farmers, farmer education, farmer income and plant age. Meanwhile, West Kalimantan shows that extension, plant age and farmer income are the main factors that significantly influence the intensity of technology adoption.

Information was obtained in Riau province that productivity shows an increase if smallholder oil palm farmers can use more inputs (urea fertilizer, SP36 and MOP). Likewise, the oil palm plantations' age with the positive effect on output implies as the average age of trees increases, oil palm productivity and labor use also had a significant effect on increasing oil palm productivity in Riau province. Meanwhile, in West Kalimantan, the area (ha) and the use of SP36 fertilizers are important factors in increasing smallholder palm oil productivity. 
The factors that influence smallholder oil palm farming's inefficiency in Riau are management patterns, technology adoption, Village Unit Cooperative membership, and access to credit. Meanwhile, in West Kalimantan, the influencing factors are management patterns, technology adoption, Village Unit Cooperative membership, and access to creditPositive significant factors that intensity level of technology adoption in Riau are access to credit, members of farmer groups and assistance to farmers, farmer education, farmer income and plant age. Meanwhile, West Kalimantan shows that extension, plant age and farmer income are the main factors that significantly influence the intensity of technology adoption.

In Riau province, information was obtained that productivity shows an increase, if smallholder oil palm farmers can use more inputs (urea fertilizer, SP36 and MOP). Likewise, the age of the oil palm plantations with the positive effect on output that implies as the average age of trees increases, oil palm productivity and labor use also had a significant effect on increasing oil palm productivity in Riau province. Meanwhile, in West Kalimantan the area (ha) and the use of SP36 fertilizers are important factors as the efforts in increasing the productivity of smallholder palm oil.

The factors that influence the inefficiency of smallholder oil palm farming in Riau are management patterns, technology adoption, Village Unit Cooperative membership and access to credit. Meanwhile in West Kalimantan, the influencing factors are management patterns, technology adoption, Village Unit Cooperative membership and access to credit

\section{Recommendations}

Oil palm productivity increases as the number of technologies adopted show that cultivation with the recommended technology will shift the production frontier to the top. Therefore, it is recommended that smallholder oil palm farmers adopt the recommended technology and practice the best in their agriculture to increase their productivity. Smallholder oil palm farmers who have not been at optimal limits must also adopt the recommended technology. The recommended technologies include certified seeds, the application of fertilizers (urea, sp36, MOP, dolomite), proper use of pesticides, plant density, and maintenance. The best management practices are, applying the right quantity and quality of fertilizers and palm oil care, such as pruning, weeding, and harvesting on time.Oil palm productivity increases as the number of technologies adopted, which shows that cultivation with the recommended technology will shift the production frontier to the top. Therefore, it is recommended that smallholder oil palm farmers adopt the recommended technology and practice the best in their agriculture, to increase their productivity. Smallholder oil palm farmers who have not been at optimal limits must also try to adopt the recommended technology. The recommended technologies include certified seeds, application of fertilizers (urea, sp36, MOP, dolomite), proper use of pesticides, plant density, and maintenance. The best management practices are, applying the right quantity and quality of fertilizers, and palm oil care such as pruning, weeding and harvesting on time.

This study revealed that the pattern of management, adoption, access to credit, and wage labor positively influenced the intensity of adoption, productivity, and technical efficiency. The study also recommended that producers must try to improve counseling and use labor in the plantation. It is also recommended that the Government and other stakeholders must provide training to oil palm farmers and employ workers about applying fertilizers correctly. Besides that, access to credit can be raised by smallholder oil palm farmers. One of the accesses that smallholders can use is the Oil Palm Plantation Fund Management Agency (BPDPKS) that is the management agency for the Oil Palm Plantation Fund. There are assistance schemes that can be utilized by smallholders, especially for replanting or through the People's Business Credit Program. One of the requirements to get access to the funding/credit is the strengthening of farmer institutions. This study revealed that the pattern of management, adoption, access to credit and wage labor positively influenced the intensity of adoption, productivity, and technical efficiency. The study also recommended that producers must try to improve counseling and use labor in the plantation. It is also recommended that the Government and other stakeholders must provide training to oil palm farmers and employ workers about applying fertilizers correctly. Besides that, access to credit can be raised by smallholder oil palm farmers. One of the accesses that can be used by smallholders is the existence of the Oil Palm Plantation Fund Management Agency (BPDPKS) that is the management agency for the Oil Palm Plantation Fund. There are assistance schemes that can be utilized by smallholders, especially for replanting or through the People's Business Credit Program. One of 
the requirements to get access to the funding / credit is the strengthening of farmer institutions.

There needs an active role from the Government (Directorate General of Plantation / Plantation Service) in providing guidance and mediation between smallholders and companies so that healthy and mutually beneficial partnerships are established between smallholders and companies. Companies can make healthy partnerships with farmers and transfer technology to smallholders. The technology packages carried out by smallholders can be better to increase productivity and quality of oil palm. There needs of the active role from the government (Directorate General of Plantation / Plantation Service) in providing guidance and mediation between smallholders and companies so that healthy and mutually beneficial partnerships are established between smallholders and companies. Companies can make healthy partnerships with farmers and also transfer technology to smallholders, so that the technology packages carried out by smallholders can be better to increase productivity and quality of oil palm.

\section{REFERENCES}

Abdulsalam Z, Nandin JA, Ahmed B. 2014 . Technical efficiency differentials in oil palm processing technologies in Cross River State, Nigeria. The Journal of Agricultural Sciences 29(3): 109-117. https://doi.org/10.4038/jas.v9i3.7424.

Alwarritzi W, Nnaseki T, Chomei Y. 2015 Analysis of the factors influencing the technical efficiency among oil palm smallholder farmers in Indonesia. Procedia Environmental Science 21: 630-638.

Amos TT. 2007. An analysis of productivity and technical efficiency of smallholder cocoa farmers in Nigeria. Journal of social science 15(2): 127133. https://doi.org/10.1080/09718923.2007.11 892573.

Bakhsh KA, Ahmad B. 2006. Technical efficiency and its determinant in potato production, evidence from Punjab, Pakistan. The Lahor Journal of Economics 11(2):1-22. https://doi.org/10.35536/ lje.2006.v11.i2.a1.

Battese GE, Coelli TJ. 1993. A stochastic frontier production function incorporating a model for technical inefficiency effects. Armidate: Department of Economics, University of new England.

Baswir et al. 2010. Pekebun Mandiri Dalam Industri
Perkebunan Sawit Di Indonesia. Sawit Watch dan Pusat Studi Ekonomi Kerakyatan Universitas Gadjah Mada (PUSTEK-UGM).

Bankole AS et al. 2018 Efficiencyevaluation of small holders palm oil production in Edo State, Nigeria. Asian Journal of Agricultural Extension, Economics \& Sociology 24(4): 1-9. https://doi. org/10.9734/AJAEES/2018/40850.

Coelli TJ, Battese GE. 1996. Identification of Factors which Influence the Technical Inefficiency of Indian Farmers. Australian Journal of Agricultural Economics 40:103-128. https://doi. org/10.1111/j.1467-8489.1996.tb00558.x.

Coelli TJ, Rao DSP, O’Donnell CJ, Battese GE. 2005. An Introduction to Efficiency and Productivity Analysis. 2nd Edition:Springer.

Euler M, Krishna V, Schwarze S, Siregar H, Qaim M. 2015. Oil palm adoption, household welfare and nutrition among smallholder farmers in Indonesia. EFForTS Discussion Paper 12, Georg-August University of Göttingen, Göttingen, Germany.

Euler M, Hoffmann MP, Fathoni Z, Schwarze S. 2016. Exploring yield gaps in smallholder oil palm production systems in Eastern Sumatra, Indonesia. Agricultural Systems 146 : 111-119. https://doi.org/10.1016/j.agsy.2016.04.007.

Euler M, Schwarze S, Siregar H, Qaim M. 2016. Oil palm expansion among smallholder farmers in Sumatra, Indonesia. Journal of Agricultural Economics 67(3): 658-676. https://doi. org/10.1111/1477-9552.12163

Ernah PP, Waibel H. 2016. Adoption of sustainable palm oil practices by Indonesian Smallholder Farmers. Journal of Southeast Asian Economies 33(3): 291-316.

Susanti EN etal. 2017. Efisiensi teknis usaha pembesaran lobster di Pulau Lombok, Nusa Tenggara Barat. Jurnal Manajemen \& Agribisnis 14(3): 230-239. https://doi.org/10.17358/jma.14.3.230

Fadwiwati AY. 2013. Pengaruh penggunaan varietas unggul terhadap efisiensi, pendapatan dan distribusi pendapatan petani jagung di Provinsi Gorontalo [Disertasi]. Bogor: Institut Pertanian Bogor.

Hasnah, Fleming E, Coelli T. 2004. Assessing the performance of a nucleus estate and smallholder scheme for oil palm production in west sumatra: a stochastic frontier analysis. Agricultural Systems (79) :17-30. https://doi.org/10.1016/ S0308-521X(03)00043-X.

Juyjaeng, Suwanmaneepong S, Mankeb P. 2019. 
TechnicalEfficiency ofOil Palm Production under a Large Agricultural Plot Scheme in Thailand. Asian Journal of Scientific Research 11(4):472479.https://doi.org/10.3923/ajsr.2018.472.479.

Kumbhakar SC, Lovell CAK. 2001. Stochastic frontier analysis. Cambridge: Cambridge University Press.

Lifianthi. 2012. Productivity And Income Peformance Comparison of Smallholder Oil Palm Plantation at Dry Land and Wet Land of South Sumatra Indonesia. ICCCP 2012: 5-6 May 2012, Kuala Lumpur, Malaysia.

Kiswanto, J. Hadipurwanta, Wijayanto. 2008. Teknologi Budidaya Kelapa Sawit. Balai Besar Pengkajian dan Pengembangan Teknologi Pertanian. Jakarta: Badan Penelitian dan Pengembangan Pertanian.

Lee JSH, Ghazoul J, Obidzinski K, Koh LP. 2014. Oil palm smallholder yields and incomes constrained by harvesting practices and type of smallholder management in Indonesia. Agronomy for Sustainable Development 34(2): 501-513. https://doi.org/10.1007/s13593-013-0159-4.
Siswati L, Ariyanto, A. 2012. Ekonomi rumah tangga petani: pola pertanian terpadu di Provinsi Riau. Jurnal Embrio V(1).

Situmorang H. 2013. Tingkat efisiensi ekonomi dan daya saing usahatani jagung di Kabupaten Dairi Provinsi Sumatera Utara [thesis]. Bogor: Institut Pertanian Bogor.

Vermeulen S, Nathalia G. 2006. Towards Better Practice in Smallholder palm oil Production, IIED.

Wiradi G. 2006. Tinjauan Ringkas Masalah Perkebunan Model-dependent smallholder. Bahan diskusi bulanan SW. Bogor: Perkumpulan Sawit Watch.

Woittiez1 LS, Slingerland M, Giller KE. 2016. Yield Gaps in Indonesian Smallholder Oil Palm Plantations: Causes and Solutions. Conference Paper. Wageningen University, The Netherlands.

Zen Z, Barlow C, Gondowarsito R. 2006. Oil palm in Indonesian socio-economic improvement- a review of options. Oil Palm Industry Economic Journal 6: 18-29. 